\title{
Transient accelerations of fetal heart rate analyzed by computerized cardiotocography in the third trimester of pregnancy
}

Ana luisa Fernandes Lauletta ${ }^{1}$, Roseli Mieko Yamamoto Nomura ${ }^{*}$, Seizo Miyadahira ${ }^{3}$, Rossana Pulcineli Vieira Francisco ${ }^{2}$, MARCELO ZugaiB ${ }^{4}$

${ }^{1}$ Undergraduate medical student at the Medicine Faculty of University of São Paulo, São Paulo, SP, Brazil

${ }^{2}$ Associate Professor, Division of Obstetrics, Department of Obstetrics and Gynecology, University of São Paulo, School of Medicine, São Paulo, SP, Brazil

${ }^{3}$ Physician assistant of Obstetrics Clinical Practice, Post-doctoral Professor at the Division of Obstetrics, Department of Obstetrics and Gynecology, University of São Paulo, School of Medicine, São Paulo, SP, Brazi

${ }^{4}$ Full Professor, Division of Obstetrics, Department of Obstetrics and Gynecology, University of São Paulo, School of Medicine, São Paulo, SP, Brazil

Work conducted at the Division of Obstetrics and Gynecology, Department of Obstetrics and Gynecology, University of São Paulo, School of Medicine, São Paulo, SP, Brazi

Article received: 4/30/2013 Accepted for publication: 8/30/2013

*Correspondence: Departamento de Obstetrícia e Ginecologia, Faculdade de Medicina da Universidade de São Paulo Address: Av. Dr. Enéas de Carvalho Aguiar $255,10^{\circ}$ andar, sala 10037 , São Paulo, SP, Brazil - ZIP Code: 05403-000 Phone: +55 $112661-6209$ Fax: 26618183 roseli.nomura@hotmail.com http://dx.doi.org/10.1590/1806-9282.60.03.017 Conflict of interest: none

\section{SUMmARY}

Objective: the aim of this study was to investigate the patterns of transient FHR accelerations (10 bpm and $15 \mathrm{bpm}$ ) in the third trimester of pregnancy, comparing the occurrence of this event before and after the 32 nd gestational week. Methods: This is a prospective study comparing the results of the computerized cardiotocography of 46 low-risk women with singleton pregnancies, maternal age between 18 and 40 years, gestational age between 28 and 40 weeks, absence of maternal morbidity and adequate fetal growth according to ultrasound. Computed Cardiotocography (8002 Sonicaid System and Fetal Care System) was performed for 30 minutes to analyze the variables of FHR.

Results: twenty-three pregnant women underwent cardiotocography before 32 weeks (mean $=29.9$ weeks, $\mathrm{SD}=1.4$ weeks) and were compared with 23 pregnant women who were examined after 32 weeks (mean $=36.3$ weeks, $\mathrm{SD}=2.5$ weeks). Regarding the characteristics of FHR, fetuses evaluated between 32 1/7 weeks and 40 weeks showed a significantly greater number of accelerations above 15 $\mathrm{bpm}$ (median $=5$, variation $0-18)$ than the group of pregnant women from 28 to 32 weeks (median $=4$, variation 0 to $10 ; P=0.048$ ). There was a significant positive correlation between the number of accelerations above $15 \mathrm{bpm}$ and the gestational age at examination ( $\mathrm{rho}=0.33 ; \mathrm{P}=0.026)$.

Conclusion: computerized cardiotocography showed an association regarding the number of transient accelerations greater than $15 \mathrm{bpm}$ in the assessment of both periods before and after 32 weeks of gestational age, suggesting the influence of the maturation of the fetal autonomic nervous system with pregnancy progression.

Uniterms: fetal heart rate, cardiotocography, gestational age.

\section{INTRODUCTION}

Fetal heart rate (FHR) is a good indicator of $f$ etal wellbeing in clinical practice, but its control mechanisms are still poorly understood. ${ }^{1}$ FHR monitoring by cardiotocography is a noninvasive method that can indicate the state of fetal oxygenation, especially in high-risk pregnancies. To analyze it, it is important to understand how the development of the sympathetic and parasympathetic nervous systems of the fetus occurs in the intrauterine period. The sympathetic and parasympathetic controls of blood flow are matured at different times during fetal development, so that the sympathetic becomes active before the parasympathetic. ${ }^{2}$

In 2008, standards of normality for interpretation of cardiotocography tracings by electronic fetal monitoring were defined. ${ }^{3}$ In this consensus, for pregnancies less than 32 weeks, the definition of transient acceleration (TA) of FHR differs from that of pregnancies up to 32 weeks. In the earlier pregnancies, the minimum amplitude required 
for the characterization of the TA is $10 \mathrm{bpm}$, whereas after 32 weeks it is $15 \mathrm{bpm}$. The presence of TA is the cardiotocographic marker that best characterizes fetal wellbeing. ${ }^{4}$

Few studies have investigated the pertinence of such limits for the definition of TA, according to gestational age. The occurrence of accelerations seems to be related to the associated cardiac response to fetal movements ${ }^{5}$ and, as the third trimester progresses, TA become more evident and extensive. ${ }^{6}$ Studies conducted in the 1980s show greater magnitude of TA after 32 weeks. ${ }^{7}$ However, there are few studies on the patterns of the FHR accelerations according to the progress of gestation by means of computerized systems. The aim of this study was to investigate the patterns of transient FHR accelerations (over $10 \mathrm{bpm}$ and $15 \mathrm{bpm}$ ) in the third trimester of pregnancy, comparing the occurrence of this event before and after the $32^{\text {nd }}$ gestational week.

\section{Methods}

Forty-six pregnant women between 28 and 40 weeks were evaluated from January 2012 to December 2012 and included in this prospective, comparative study at a university hospital. The research project and the free and informed consent were approved by the Ethics in Research Committee (protocol number: 0818/11). Women with low risk pregnancies were included, without clinical or obstetric morbidities, followed up during prenatal care in the institution, according to the following inclusion criteria: single and live fetus, maternal age between 18 and 40 years, gestational age between 28 and 40 weeks, absence of maternal morbidity, adequate fetal growth according to ultrasonography and no fetal malformations. Cases of small for gestational age infant those with congenital anomaly or malformation detected after birth were excluded.

Sonicaid computerized cardiotocography (Sonicaid System 8002 and Fetal Care System, Oxford, United Kingdom), with software for objective analysis of parameters was used. On the day of consultation for prenatal evaluation, the research was explained to pregnant women, and they were invited to participate. Who agreed were subjected to computerized cardiotocography. The examination was performed with the patient in sitting position, using two transducers positioned on the maternal abdomen, one over the region where the back of the fetus would be positioned, best location for auscultation of the fetal heartbeat (to collect the fetal heartbeat) and another in the uterine fundus (for uptake of uterine contractions), both secured by elastic straps and comfortably. To cap- ture the fetal movements, the patients received an event marker, a handheld device coupled to the cardiotocograph, and was instructed to trigger it whenever she noticed any movement of the fetus. The examination was performed for 30 minutes.

The computerized system analyzes the cardiotocographic trace during periods of 3.75 seconds $(1 / 16$ of a minute). In each period, the system evaluates the average length of time intervals between successive fetal heartbeats, measured in milliseconds (ms); and calculates the average FHR for each period and also the differences between adjacent periods. The baseline FHR is calculated by averaging the pulse intervals recorded in all periods of low variance (when periods of low variance are not observed, the calculation is derived from the analysis of all periods). Transient accelerations of FHR with greater amplitude to 10 bpm and 15 bpm are detected; as well as slowdown in FHR. High variation episodes are characterized as at least five of six consecutive minutes in which the amplitude of the pulse intervals is greater than $32 \mathrm{~ms}$, while episodes of low variation are defined when at least during five of six consecutive minutes the amplitude of pulse intervals is less than $30 \mathrm{~ms}$. The short-term variation (in ms) corresponds to the average values of FHR differences between adjacent periods of 3.75 seconds.

Patients included in the study were grouped according to gestational age at which cardiotocography was performed in two groups: group 1, 28-32 weeks and group 2,32 weeks and 1 day to 40 weeks of pregnancy. The characteristics of the study population and birth data are shown in Table 1.

For statistical analysis we used the Medcalc (Medcalc Software, Belgium) software version 11.5.1.0. The sample size calculation was performed considering type I error (alpha) at 0.05 and type II error (beta) at 0.20 to detect a $10 \%$ difference in the number of TA before and after 32 weeks, with a mandatory minimum of 23 cases in each group, totaling 46 cases. The variables were analyzed descriptively presenting absolute and relative frequencies, minimum and maximum values, medians, means and standard deviations. The comparison of groups was performed using Student's T test for unpaired samples when the distribution of the variables was normal. For variables that were not normally distributed, the nonparametric Mann Whitney U test was used. Categorical data were compared using chi-square or Fisher's exact test. The Spearman correlation coefficients (rho) were calculated among the several parameters of FHR and gestational age at examination. The level of significance was set at $\mathrm{p}<0.05$ for all tests. 


\begin{tabular}{|c|c|c|c|}
\hline Parameters & $\begin{array}{l}\text { Group } 1 \\
\text { GA from } 28 \text { to } \\
32 \text { weeks } \\
(n=23)\end{array}$ & $\begin{array}{l}\text { Group } 2 \\
\text { GA from } 321 / 7 \text { to } \\
40 \text { weeks } \\
(n=23)\end{array}$ & $\mathrm{P}$ \\
\hline $\begin{array}{l}\text { Mother's age } \\
\text { (years) }\end{array}$ & $27.0(5.5)$ & $26.2(7.4)$ & 0.685 \\
\hline $\begin{array}{l}\text { Gestational } \\
\text { age at } \\
\text { examination } \\
\text { (weeks) }\end{array}$ & $29.9(1.4)$ & $36.3(2.5)$ & - \\
\hline
\end{tabular}

\begin{tabular}{l|l|l|l}
\hline \multicolumn{5}{l}{ Skin color } \\
\cline { 1 - 2 } White & $11(47.8 \%)$ & $14(60.8 \%)$ & 0.554 \\
\hline Non-white & $12(52.1 \%)$ & $9(39.1 \%)$ & \\
\hline
\end{tabular}

\begin{tabular}{l|l|l|l}
\hline \multicolumn{5}{l|}{ Parity } & $14(60.8 \%)$ & $15(65.2 \%)$ & 0.203 \\
\hline 0 & $9(39.1 \%)$ & $8(34.7 \%)$ & \\
\hline$\geq 1$ & $39.4(1.3)$ & $40.0(0.9)$ & 0.081 \\
\hline $\begin{array}{l}\text { Gestational } \\
\text { age at delivery }\end{array}$ & $3368(341)$ & $3237(263)$ & 0.153 \\
\hline $\begin{array}{l}\text { Weight of } \\
\text { newborn }\end{array}$ & & & \\
\hline
\end{tabular}

Type of birth

\begin{tabular}{l|l|l|l}
\hline C-section & $10(43.5 \%)$ & $11(47.8 \%)$ & 1.000 \\
\cline { 1 - 3 } Vaginal & $13(56.5 \%)$ & $12(52.2 \%)$ & \\
\hline
\end{tabular}

Sex of the newborn

\begin{tabular}{l|l|l|l}
\hline Female & $11(47.8 \%)$ & $10(43.5 \%)$ & 1.000 \\
\cline { 1 - 3 } Male & $12(52.2 \%)$ & $13(56.5 \%)$ & \\
\hline
\end{tabular}

Data expressed as mean (SD) or $\mathrm{n}(\%)$

\section{Results}

Twenty-three pregnant women in group 1 were compared to 23 pregnant women in group 2 regarding the characteristics of FHR assessed by computerized cardiotocography. The analysis of these parameters is shown in Table 2. There was no significant difference between the two groups according to the number of fetal movements per hour $(p=0.325)$, baseline FHR $(p=0.717)$, number of TA greater than $10 \mathrm{bpm}(\mathrm{p}=0.492)$, episodes of high variation $(p=0.240)$, episodes of low variation $(\mathrm{p}=0.076)$, and short-term variation $(\mathrm{p}=0.287)$. The group with gestational age between 32 and 40 weeks had significantly higher median number of TA greater than $15 \mathrm{bpm}$ (median $=5$, variation $0-18$ ) than the group of pregnant women from 28 to 32 weeks (median $=4$, variation 0 to $10 ; \mathrm{p}=0.048$ ).

TABLE 2 Fetal parameters analyzed by computerized cardiotocography according to gestational age at the time of examination

\begin{tabular}{|c|c|c|c|}
\hline Parameters & $\begin{array}{l}\text { Group } 1 \\
\text { GA from } 28 \text { to } \\
32 \text { weeks } \\
(n=23)\end{array}$ & $\begin{array}{l}\text { Group } 2 \\
\text { GA from } 321 / 7 \\
\text { to } 40 \text { weeks } \\
(n=23)\end{array}$ & $\mathrm{P}$ \\
\hline $\begin{array}{l}\text { Fetal movements } \\
\text { per hour }\end{array}$ & $18(0-120)$ & $22(0-212)$ & 0.325 \\
\hline $\begin{array}{l}\text { Fetal heart rate, } \\
\text { bpm }\end{array}$ & $135(125-157)$ & $\begin{array}{l}137(119- \\
161)\end{array}$ & 0.717 \\
\hline $\begin{array}{l}\text { Number of } \\
\text { accelerations }>10 \\
\text { bpm }\end{array}$ & $2(0-5)$ & $3(0-20)$ & 0.492 \\
\hline $\begin{array}{l}\text { Number of } \\
\text { accelerations > } 15 \\
\text { bpm }\end{array}$ & $4(0-10)$ & $5(0-18)$ & 0.048 \\
\hline $\begin{array}{l}\text { Duration of } \\
\text { episodes of high } \\
\text { variation, min }\end{array}$ & $17(0-38)$ & $13(0-28)$ & 0.240 \\
\hline $\begin{array}{l}\text { Duration of } \\
\text { episodes of low } \\
\text { variation, min }\end{array}$ & $0(0-20)$ & $5(0-29)$ & 0.076 \\
\hline $\begin{array}{l}\text { Short-term } \\
\text { variation of FHR, } \\
\text { ms }\end{array}$ & $9.5(4.2-15.4)$ & $8.9(3.4-16.6)$ & 0.287 \\
\hline
\end{tabular}

Data expressed as median (minimum - maximum).

Correlation analyses between gestation age at the performance of cardiotocography and FHR parameters was carried out and the results are shown in Table 3 . We found a significant positive correlation between the number of TA greater than $15 \mathrm{bpm}$ and gestational age $(\mathrm{rho}=0.33$, $\mathrm{P}=0.026$ ). The distribution of cases according to the number of TA greater than $15 \mathrm{bpm}$ and gestational age is shown in the graph of Figure 1. 
TABLE 3 Correlations between gestational age in weeks and fetal parameters evaluated by computerized cardiotocography $(n=46)$

\begin{tabular}{|c|c|c|c|}
\hline Parameter & $\begin{array}{l}\text { Spearman } \\
\text { coefficient } \\
\text { (rho) }\end{array}$ & $\mathrm{P}$ & $95 \% \mathrm{Cl}$ p/ rho \\
\hline Baseline FHR, bpm & -0.06 & 0.716 & -0.34 to 0.24 \\
\hline $\begin{array}{l}\text { Fetal movements } \\
\text { per hour }\end{array}$ & 0.21 & 0.163 & -0.09 to 0.47 \\
\hline $\begin{array}{l}\text { Number of } \\
\text { accelerations > } 10 \\
\text { bpm }\end{array}$ & 0.25 & 0.095 & -0.04 to 0.50 \\
\hline $\begin{array}{l}\text { Number of } \\
\text { accelerations > } 15 \\
\text { bpm }\end{array}$ & 0.33 & 0.026 & 0.04 to 0.57 \\
\hline $\begin{array}{l}\text { Duration of } \\
\text { episodes of high } \\
\text { variation, min }\end{array}$ & -0.02 & 0.878 & -0.31 to 0.27 \\
\hline $\begin{array}{l}\text { Duration of } \\
\text { episodes of low } \\
\text { variation, min }\end{array}$ & 0.18 & 0.228 & -0.12 to 0.45 \\
\hline $\begin{array}{l}\text { Short-term variation } \\
\text { of FHR, ms }\end{array}$ & -0.06 & 0.699 & -0.34 to 0.24 \\
\hline
\end{tabular}

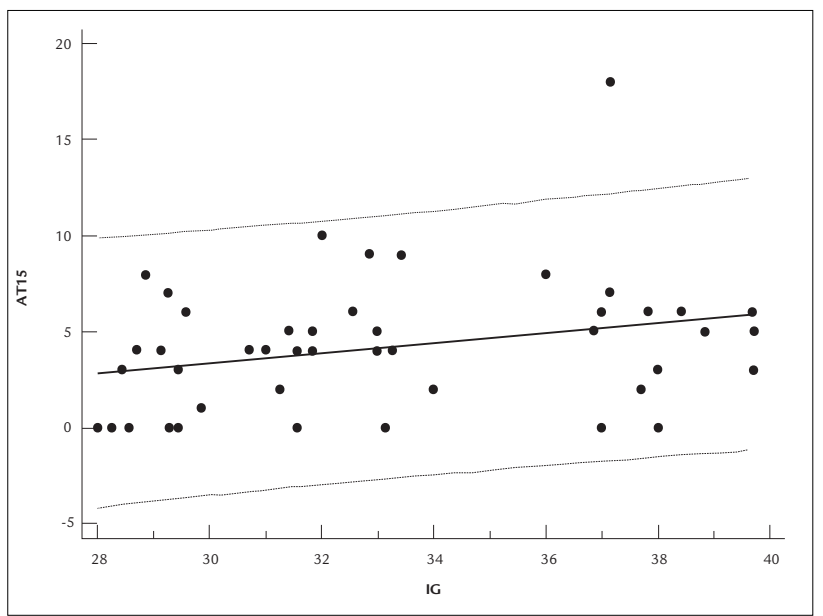

FIGURE 1 Distribution of cases according to the number of transient accelerations of fetal heart rate greater than 15 bpm (TA15) in relation to gestational age (GA).

\section{Discussion}

This study confirms that there are differences in the patterns of FHR accelerations when comparing the third tri- mester of pregnancies under and over 32 weeks. The number of TA above $15 \mathrm{bpm}$ is higher when the computerized cardiotocography is performed in pregnancies over 32 weeks, supporting the international criteria adopted for the interpretation of FHR by electronic fetal monitoring. ${ }^{3}$

However, the other parameters analyzed by computerized cardiotocography showed no significant difference when comparing the groups, which helps to support the interpretation of cardiotocography tracings at earlier gestations.

Evidence shows that high vagal tone is associated with more efficient regulation of fetal homeostasis in the end of pregnancy. ${ }^{8}$ The trajectory of neurodevelopment is associated with increased variability of the FHR after 28 weeks, ${ }^{9}$ and is indicative of the development of the neural control of the fetus, with prognostic value for its operation after birth). ${ }^{9}$ The maturation of the autonomic nervous system in the third trimester promotes changes in FHR patterns, indicating progressive interaction between the sympathetic and parasympathetic systems, so that, apart from increased variability, accelerations of FHR in response to fetal movements arise. These characteristics of FHR are analyzed by means of cardiotocography, and this method has been used for decades for monitoring fetal wellbeing. Currently, this test is used to analyze the risk of fetal death in complicated pregnancies, both on account of pre-existing maternal diseases or problems in the developing fetus. ${ }^{10}$

The interpretation of cardiotocography tracings can be performed based on visual examination or by computerized systems. Visual analysis, applied since the method was introduced, may be affected by the subjectivity of the evaluator, which limits the reproducibility of the results. To avoid possible errors of visual evaluation, computerized analysis of FHR was developed. Cardiotocography is the method that allows the study of FHR and its changes in response to uterine activity and oxygenation, also allowing the study of the physiology of FHR regulation according to development at different gestational ages. ${ }^{11}$

FHR acceleration in response to the movements is a normal reaction of the fetus, and both its absence and marked reduction suggest fetal hypoxemia. ${ }^{6}$ The decrease in the absolute frequency of FHR accelerations can be a useful parameter for early detection of hypoxemia, before severe metabolic acidosis or irreversible damage to the fetus occur. ${ }^{6}$

It was demonstrated that before 32 weeks accelerations of $10 \mathrm{bpm}$ prevail, whereas only after that point accelerations of $15 \mathrm{bpm}$ begin to become more evident. ${ }^{12}$ 
In a study carried out in 1990, the authors demonstrated, with traditional cardiotocography, that the criterion of $10 \mathrm{bpm}$ would be more appropriate than $15 \mathrm{bpm}$ before the $30^{\text {th }}$ week of pregnancy. ${ }^{13}$ More recently, new studies have confirmed the increased frequency of accelerations after 32 weeks, as assessed by computerized cardiotocography, ${ }^{14,15}$ confirming previous results and supporting the importance of these values once again to assess the proper development of the fetus.

The prediction of fetal wellbeing by electronic FHR monitoring requires the interpretation of multiple parameters of the trace. The accelerations are defined by basic components such as duration and amplitude. Accelerations are indicators for the assessment of fetal well-being, both before and after birth, and the definition of FHR accelerations depends more on amplitude than on the duration in minutes. ${ }^{16}$ As pregnancy progresses, the vagal dominance is progressively established in the fetus until birth. This is associated with more efficient regulation of fetal homeostasis during late pregnancy ${ }^{8}$ and after delivery, resulting in gradual decline of the baseline heart rate. ${ }^{16}$ These changes can be explained by the predominance of the sympathetic nervous system in preterm infants, as opposed to the predominance of the parasympathetic system after birth, as observed in some studies. ${ }^{13.14,17}$ Better knowledge of these changes leads to a more correct interpretation of cardiotocography tracings, especially in high-risk pregnancies. ${ }^{18}$

In conclusion, computerized cardiotocography showed an association regarding the number of transient accelerations greater than $15 \mathrm{bpm}$ in the assessment of both periods before and after 32 weeks of gestational age, suggesting the influence of the maturation of the fetal autonomic nervous system with pregnancy progression.

\section{FINANCIAL SUPPORT}

Scientific initiation scholarship from the São Paulo State Research Foundation (FAPESP) for student Ana Luisa Fernandes Lauletta (Process no. 2011/20140-6).

\section{Resumo}

Acelerações transitórias da frequência cardíaca fetal analisada pela cardiotocografia computadorizada no terceiro trimestre da gestação

Objetivo: o objetivo deste estudo foi investigar os padrões das acelerações transitórias da FCF (de 10 e 15 bpm) no terceiro trimestre da gestação, comparando a ocorrência desse evento antes e após a $32^{\mathrm{a}}$ semana gestacional.
Métodos: trata-se de estudo prospectivo comparando os resultados do exame de cardiotocografia computadorizada de 46 gestantes de baixo risco, com feto único, idade materna entre 18 e 40 anos, idade gestacional entre 28 e 40 semanas, ausência de morbidades maternas e crescimento fetal adequado pela ultrassonografia. Foi realizada a cardiotocografia computadorizada (Sonicaid System 8002 e Fetal Care System) por 30 minutos para análise das variáveis da FCF.

Resultados: vinte e três gestantes que realizaram a cardiotocografia antes da $32^{\mathrm{a}}$ semana (média $=29,9$ semanas, $\mathrm{DP}=1,4$ semanas) foram comparadas com 23 que realizaram o exame após a $32^{\mathrm{a}}$ semana (média $=36,3$ semanas, $\mathrm{DP}=2,5$ semanas). Quanto às características da FCF, os fetos avaliados entre $321 / 7$ semanas e 40 semanas apresentaram número significativamente maior de acelerações acima de $15 \mathrm{bpm}$ (mediana $=5$, variação $0 \mathrm{a}$ 18) que o grupo de gestantes de 28 a 32 semanas (mediana $=4$, variação 0 a $10 ; \mathrm{P}=0,048)$. Houve correlação significativa e positiva entre o número de acelerações transitórias acima de $15 \mathrm{bpm}$ e a idade gestacional no momento do exame (rho $=0,33 ; \mathrm{P}=0,026$ ).

Conclusão: a cardiotocografia computadorizada revelou associação entre o número de acelerações transitórias acima de $15 \mathrm{bpm}$ quando avaliados os períodos antes e após 32 semanas de idade gestacional, sugerindo influência da maturação do sistema nervoso autônomo fetal com a progressão da gestação.

Unitermos: frequência cardíaca fetal; cardiotocografia; idade gestacional.

\section{References}

1. Dawes GS, Moulden M, Redman CW. Short-term fetal heart rate variation, decelerations, and umbilical flow velocity waveforms before labor. Obstet Gynecol. 1992;80(4):673-8.

2. Assali NS, Brinkman CR, Woods JR, Dandavino A, Nuwayhid B. Development of neurohumoral control of fetal, neonatal, and adult cardiovascular functions. Am J Obstet Gynecol. 1977;129(7):748-59.

3. Macones GA, Hankins GD, Spong CY, Hauth J, Moore T. The 2008 National Institute of Child Health and Human Development workshop report on electronic fetal monitoring: update on definitions, interpretation, and research guidelines. Obstet Gynecol. 2008;112(3):661-6.

4. Lee CY, Di Loreto PC, Logrand B. Fetal activity acceleration determination for the evaluation of fetal reserve. Obstet Gynecol. 1976;48(1):19-26.

5. Timor-Tritsch IE, Dierker LJ, Zador I, Hertz RH, Rosen MG. Fetal movements associated with fetal heart rate accelerations and decelerations. Am J Obstet Gynecol. 1978;131(3):276-80.

6. Gagnon R, Hunse C, Bocking AD. Fetal heart rate patterns in the small-forgestational-age human fetus. Am J Obstet Gynecol. 1989;161(3):779-84.

7. Gagnon R, Campbell K, Hunse C, Patrick J. Patterns of human fetal heart rate accelerations from 26 weeks to term. Am J Obstet Gynecol. 1987;157(3):743-8.

8. Groome LJ, Mooney DM, Holland SB, Smith LA, Atterbury JL, Loizou PC. Human fetuses have nonlinear cardiac dynamics. J Appl Physiol. 1999;87(2):530-7. 
9. DiPietro JA, Bornstein MH, Hahn CS, Costigan K, Achy-Brou A. Fetal heart rate and variability: stability and prediction to developmental outcomes in early childhood. Child Dev. 2007;78(6):1788-98.

10. ACOG practice bulletin. Antepartum fetal surveillance. Number 9, October 1999 (replaces Technical Bulletin Number 188, January 1994). Clinical management guidelines for obstetrician-gynecologists. Int J Gynaecol Obstet. 2000;68(2):175-85.

11. Freeman RK, Anderson G, Dorchester W. A prospective multi-institutional study of antepartum fetal heart rate monitoring. I. Risk of perinatal mortality and morbidity according to antepartum fetal heart rate test results. Am J Obstet Gynecol. 1982;143(7):771-7.

12. Park YS, Koh SK, Hoh JK, Park MI. Difference of fetal heart rate accelerations based on 10 and 15 beats per minute. J Obstet Gynaecol Res. 2010;36(2):291-5

13. Pillai M, James D. The development of fetal heart rate patterns during normal pregnancy. Obstet Gynecol. 1990;76(5 Pt 1):812-6.
14. Park MI, Hwang JH, Cha KJ, Park YS, Koh SK. Computerized analysis of fetal heart rate parameters by gestational age. Int J Gynaecol Obstet. 2001;74(2):157-64.

15. Serra V, Bellver J, Moulden M, Redman CW. Computerized analysis of normal fetal heart rate pattern throughout gestation. Ultrasound Obstet Gynecol. 2009;34(1):74-9.

16. Hoh JK, Park MI, Park YS, Koh SK. The significance of amplitude and duration of fetal heart rate acceleration in non-stress test analysis. Taiwan J Obstet Gynecol. 2012;51(3):397-401.

17. Nomura RM, Campos CF, Bessa JF, Miyadahira S, Zugaib M. [Comparison of fetal heart rate patterns in the second and third trimesters of pregnancy]. Rev Bras Ginecol Obstet. 2010;32(9):420-5.

18. Nemer DS, Nomura RM, Ortigosa C, Liao AW, Zugaib M. Computerized cardiotocography in pregnancies complicated by maternal asthma. J Matern Fetal Neonatal Med. 2012;25(7):1077-9. 